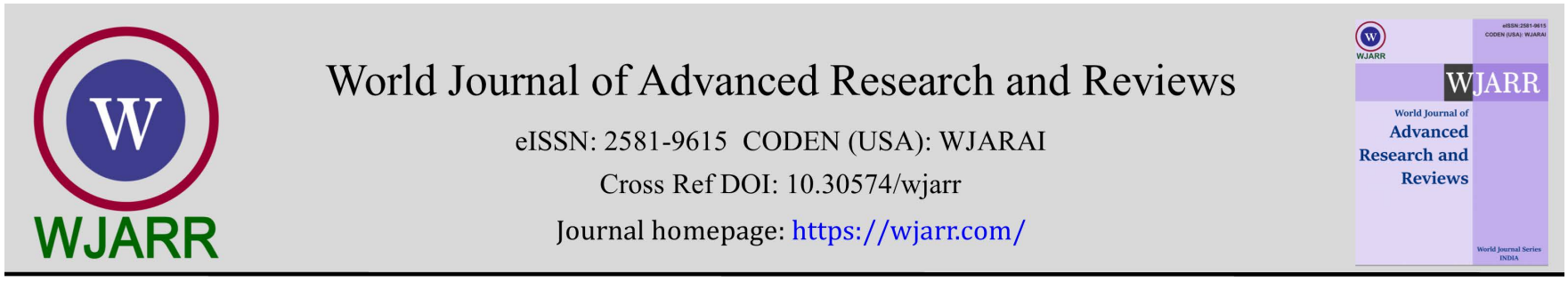

(CASE STUDY)

\title{
Prevalence of gingival enlargement in patients with fixed orthodontic aparatology: A cross-sectional observational study.
}

\author{
Mónica Alexandra Soliz, María José Ortiz *, and Andrea Soledad Carvajal \\ ${ }^{1}$ Dentist. Faculty of Dentistry, University of Cuenca, Ecuador. \\ ${ }^{2}$ Student of the Faculty of Dentistry, University of Cuenca, Ecuador. \\ 3 Professor of the Faculty of Dentistry, University of Cuenca, Ecuador.
}

World Journal of Advanced Research and Reviews, 2021, 09(02), 045-055

Publication history: Received on 27 January 2021; revised on 06 Februay 2021; accepted on 08 Februay 2021

Article DOI: https://doi.org/10.30574/wjarr.2021.9.2.0042

\begin{abstract}
Gingival enlargement (GE) is an excessive growth of the gum, which causes functional and aesthetic disorders in individuals. Its etiology is closely related to the dental biofilm accumulation; however, other local and systemic factors can modify the response to these irritants, worsening the condition. This study objective is to determine the GE prevalence in patients with fixed orthodontic appliances and its distribution. A cross-sectional study was conducted in 105 patients older than 15 years, attended at the Postgraduate Orthodontic Clinic of the University of Cuenca. A questionnaire provided information on: sex, age, use of mouthwash, prior periodontal treatment, and stationary apparatus time use. A clinical examination was carried out to determine the periodontal biotype, cementation additives material excess, and the probing depth was evaluated with a periodontal probe PCP 11.5. Any value equal to or greater than $3.5 \mathrm{~mm}$ was considered as GE and classified according to grade and location. As a result, a GE prevalence of $65.7 \%$ was found, with a unique statistically significant association between GE and the fixed apparatus time use, where those patients who used it for more than 12 months, had a higher risk ( $\mathrm{p}=0.0039$; OR: 3.42; 95\% CI: 1.46-8.02). Grade I GE (papillary) was the most prevalent; vestibular surfaces and lower anterior teeth were the most frequent locations.
\end{abstract}

Keywords: Gingival Enlargement; Excessive Gingival Growth; Gingival Hyperplasia; Fixed Orthodontics; Orthodontic Appliances.

\section{Introduction}

Gingival enlargement is a frequent condition among the population with fixed orthodontic apparatus, which presents itself as an increase in gum volume; giving rise to the formation of pseudosacs, therefore, there is no loss of insertion [1] . Excessive gingival growth, which is evident in patients with fixed orthodontic aparatology, corresponds to chronic inflammatory gingival enlargement caused by prolonged exposure to dental biofilm [2], which removal is difficult due to the presence of attachments used during orthodontic therapy [3] . Thus, it differs from those gingival enlargements also of inflammatory but acute origin such as abscesses, or from those of neoplastic origin [4] . are also distinguished from enlargements caused by systemic factors, including those modulated by hormonal changes [5]; those generated as side effects of the anticonvulsant drugs use such as phenytoin [6], calcium blockers such as nifedipine [7], or immunosuppressant's [8] such as cyclosporine [9], whose effect depends on the dose ingested by the patient, at a lower dose, less effect [10]; and those resulting in systemic diseases such as leukemia, lymphoma, neurofibromatosis, hereditary gingival fibromatosis, some granulomatous disorders, Sturge-Weber syndrome, and nutritional deficiencies, among others [11].

\footnotetext{
* Corresponding author: María José Ortiz Figueroa

Student of the Faculty of Dentistry, University of Cuenca. Ecuador. 
According to its extent, gingival enlargement, can be localized, when it affects the gum adjacent to a single tooth or group of teeth; and generalized when it affects the gum of the entire oral cavity. On the other hand, gingival enlargement can be classified according to its distribution, in marginal, papillary, diffuse (if it affects the marginal gum together, adhered and papillary), and discrete (if it is isolated similar to a tumor) [12].

This gingival enlargement begins as a tumor, mass or nodule, sepal or pedunculate that may involve the interdental papilla, marginal and/or adhered gums, depending on the location of the irritant; it may proliferate to cover part of the dental crown [13]. The clinical characteristics of GE appear to reflect their various stages of development; in the early stages they appear red, with ulcerated surfaces, and bleed spontaneously or at the touch; whereas in the later stages they may be pedicled growths, sessile or leaf-shaped, and have a mature, firm, avascular, and fibrous appearance [14].

Histologically, there is a hyperkeratinized and acanthotic epithelium, as well as an increase in both disorganized collagen fibers and fibroblasts; there is also the presence of chronic inflammatory infiltrate and few blood vessels [15]

The maintenance of healthy gingival tissues is a challenge during orthodontic treatment. The correct and timely diagnosis of a gingival enlargement is ideal for the development and completion of orthodontic treatment. This is reflected in the functional and aesthetic satisfaction of the patient. The prevention of this condition can be focused on multidisciplinary management among specialists who periodically control the treatment of the patient, promoting the timely elimination of dental biofilm as a local factor, and reducing retentive sites. The treatment of gingival enlargement includes a first hygienic phase focused on local etiologic factors elimination, which consists of the removal of hard and soft deposits [16]; includes teaching oral hygiene, detailing, and chemical agents support for plate control, such as chlorhexidine in concentrations of $0.1 \%$ to $0.2 \%$, used for its substantivity property to inhibit plate formation, reducing, and limiting excessive gingival growth [17]. When the therapy directed to the local etiological factor does not achieve an adequate resolution of the gingival overgrowth and this persists, surgical procedures are indicated, such as gingivoplasty, which intends to re-turn the gum, or gingivectomy to remove the area of the enlarged gums [18]. These procedures are usually performed using scalpels, lasers, and electrosurgery [19]. In this way you can achieve gingival contours that allow easy hygienisation, and optimal aesthetic results for the patient.

The objective of this study was to determine the prevalence of gingival enlargement in patients with fixed orthodontic apparatus and its distribution according to sex, age, fixed aparatology use time, periodontal biotype, previous periodontal treatment for later gingival enlargement classification according to its degree and location.

\section{Methodology}

A cross-sectional observational study was carried out, whose known population sample calculation (135 patients aged 16 years or older) considered the following restrictions: confidence level of $95 \%$, with an expected frequency of $50 \%$, and a margin of error of 5\%. With the possible losses' correction, a sample of 105 individuals who attend the clinic of the postgraduate course of Orthodontics of the Faculty of Dentistry of the University of Cuenca was established. Patients were selected through a convenience sampling strategy, using information provided in the medical records.

Each patient was informed about the study purpose and data collection process. The participation acceptance was confirmed by their signature and of their representative in the informed consent and assent, if applicable.

All the study design bioethics principles required were in accordance with the Declaration of Helsinki and the obtained information was recorded in the University of Cuenca Research Directorate Dentistry Faculty authorized form, as part of this investigation, while maintaining the respective confidentiality. We included individuals with fixed apparatus, older than 15 years, with their permanent dentition in full eruption. Patients in gestation, with systemic diseases or who are under medication that may cause gingival enlargement such as phenytoin, cyclosporine, and nifedipine, were excluded from the study.

In the interview with each participant, information was obtained regarding their age, sex, time of use of fixed appliances, use of mouthwash and trademark to identify the use of chlorhexidine, whether he received previous periodontal treatment to remove biofilm and/or dental calculus, and whether he received motivation and oral hygiene education prior to his orthodontic treatment.

The clinical examination included periodontal biotype differentiation using visual inspection and probe transparency technique [20], distinguishing between fine or coarse biotype; depending on whether it was possible or not, the probe visualization through the gingival margin. Additionally, excess adhesion material was identified in the apparatus additions; and periodontal probing was performed to determine the presence and location of gingival enlargement. This 
scan was performed using a basic sterile periodontal diagnostic set, consisting of an intrabuccal mirror number 5 , explorer, cotton tong, and periodontal probe PCP 11.5 (Hu-Friedy), whose calibration makes it possible to easily identify any depth equal to or greater than $3.5 \mathrm{~mm}$, thanks to its black segment $(3.5 \mathrm{~mm}$ to $5.5 \mathrm{~mm})$, figure 1 .

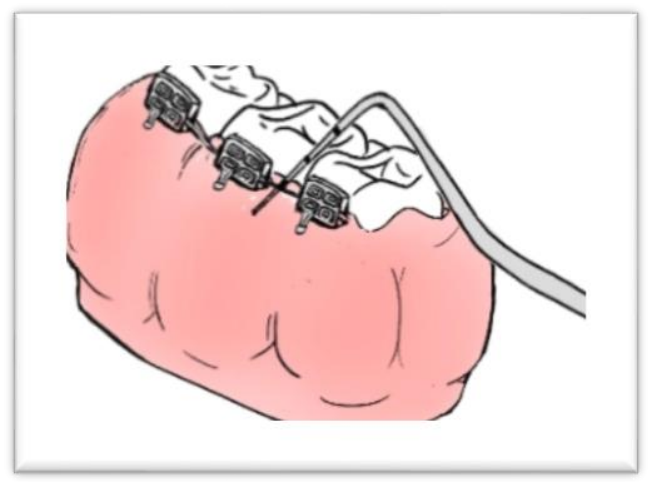

Figure 1 Determination of gingival enlargement with PCP11.5 probe

The data collection was obtained by a single observer, determining gingival enlargement at any hole depth equal to or greater than $3.5 \mathrm{~mm}$ according to the instrument used as shown in Figure 2. In cases of gingival enlargement, its location was recorded according to tooth and surface; in addition to its classification according to the following scale: grade I: enlargement limited to the interdental papilla, grade II: it involves the papilla and marginal gum, grade III: covers three quarters or more of the crown [21].
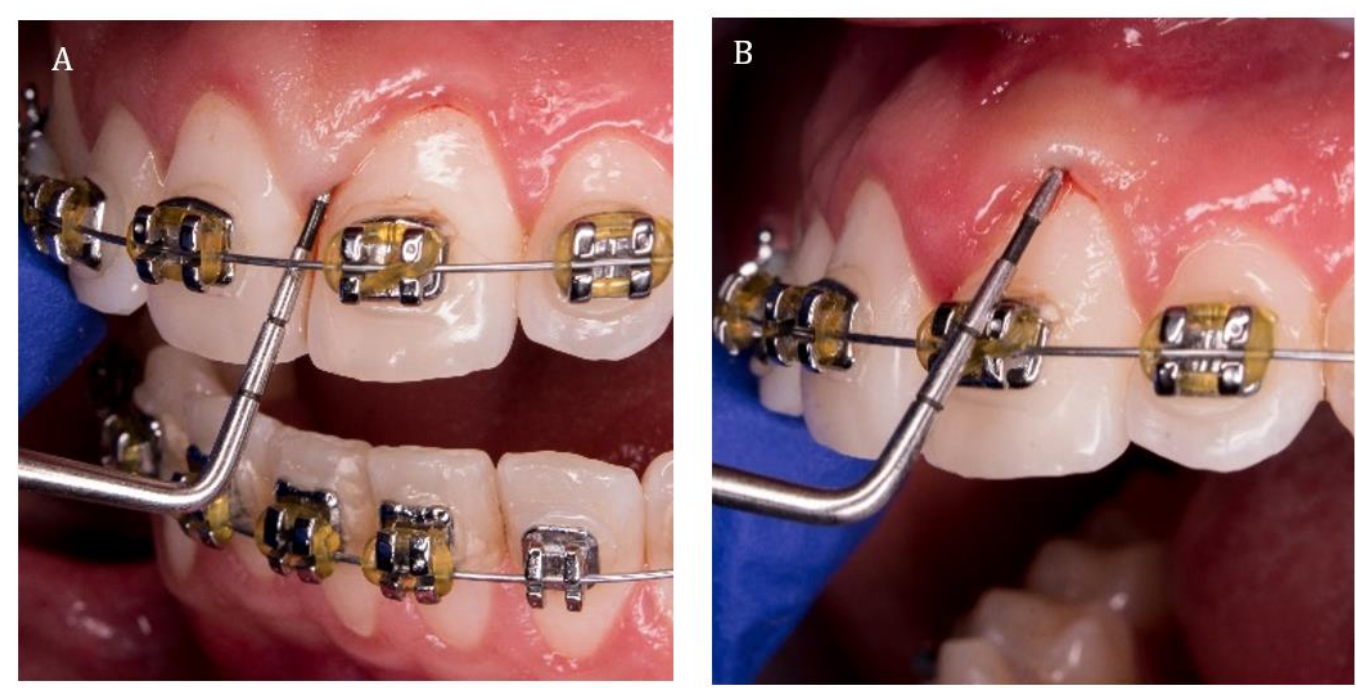

Figure 2 A-B. Periodontal probing to identify the presence of gingival enlargement with periodontal probe PCP 11.5 . Courtesy of Andrés García.

The information collected was recorded in a Microsoft Excel spreadsheet (Office, 2013 version), to generate the database, while IBM SPSS Statistics (version 20.0) was used for its analysis. The results were described as measures of central tendency, absolute and relative frequencies. In addition, the Chi square test was explored for each variable, in relation to the frequency of gingival enlargement, in order to identify possible associations.

\section{Results}

The majority of participants in the study were women; with respect to age, a significant majority of young people and young adults in the 16-25 age range were examined, as shown in Table 1. 
Table 1 Characterization of the sample according to the variables recorded.

\begin{tabular}{|c|c|c|c|}
\hline Variable & & $\mathbf{N}$ & $\%$ \\
\hline Age & $\begin{array}{l}16-22 \text { years } \\
26 \text { years or more }\end{array}$ & $\begin{array}{l}92 \\
13\end{array}$ & $\begin{array}{l}87,6 \\
12,4\end{array}$ \\
\hline Sex & $\begin{array}{l}\text { Male } \\
\text { Female }\end{array}$ & $\begin{array}{l}44 \\
61\end{array}$ & $\begin{array}{l}41,9 \\
58,1\end{array}$ \\
\hline Periodontal biotype & $\begin{array}{l}\text { Thick } \\
\text { Thin }\end{array}$ & $\begin{array}{l}60 \\
45\end{array}$ & $\begin{array}{l}57,1 \\
42,9\end{array}$ \\
\hline Gingival enlargement presence & $\begin{array}{l}\text { Yes } \\
\text { No }\end{array}$ & $\begin{array}{l}69 \\
36\end{array}$ & $\begin{array}{l}65,7 \\
34,3\end{array}$ \\
\hline Appliances use time & $\begin{array}{l}1 \text { year } \\
2 \text { years } \\
3 \text { years } \\
4 \text { years or more }\end{array}$ & $\begin{array}{l}36 \\
41 \\
15 \\
13\end{array}$ & $\begin{array}{l}32.9 \\
39,6 \\
14.7 \\
12,8\end{array}$ \\
\hline Adhesion resin excess & $\begin{array}{l}\text { Yes } \\
\text { No }\end{array}$ & $\begin{array}{l}8 \\
97\end{array}$ & $\begin{array}{l}7,6 \\
92,4\end{array}$ \\
\hline Prior detailing & $\begin{array}{l}\text { Yes } \\
\text { No }\end{array}$ & $\begin{array}{l}71 \\
34\end{array}$ & $\begin{array}{l}67,6 \\
32,4\end{array}$ \\
\hline $\begin{array}{l}\text { Time from detailing to } \\
\text { cementation of equipment }\end{array}$ & $\begin{array}{l}\leq \text { a month } \\
>\text { a month }\end{array}$ & $\begin{array}{l}71 \\
34\end{array}$ & $\begin{array}{l}67,6 \\
32,4\end{array}$ \\
\hline $\begin{array}{l}\text { Oral hygiene education and prior } \\
\text { motivation }\end{array}$ & $\begin{array}{l}\text { Yes } \\
\text { No }\end{array}$ & $\begin{array}{l}68 \\
37\end{array}$ & $\begin{array}{l}64,8 \\
35,2\end{array}$ \\
\hline $\begin{array}{l}\text { Use of coluthora with } \\
\text { chlorhexidine }\end{array}$ & $\begin{array}{l}\text { Yes } \\
\text { No }\end{array}$ & $\begin{array}{l}36 \\
69\end{array}$ & $\begin{array}{l}34,3 \\
65,7\end{array}$ \\
\hline TOTAL & & 105 & 100 \\
\hline
\end{tabular}

Source: The database.

As a result of the clinical examination, a majority of participants with thick periodontal biotype were determined, and only a small proportion of cases with excess adhesion material used in cementation of the attachments outside the margins of the brackets or bands were determined.

The device use time was measured in months, the minimum value was one month and the maximum value was 72 months with an average of 20.7 months; later the variable was grouped in years for the association analyses. Only 36 out of 105 participants (34.2\%) used mouthwash, which was consulted about the brand name of the product, to define whether or not it contained chlorhexidine.

Of the 105 patients evaluated, 69 presented gingival enlargement, which represents a prevalence of 65.7\%; having a greater frequency in vestibular surfaces than in palatines, as indicated in the detail of the affected dental surfaces, in Table 2. 
Table 2 Distribution of gingival enlargement by area.

\begin{tabular}{|c|c|c|c|c|c|c|c|c|c|c|}
\hline \multirow{3}{*}{$\begin{array}{l}\text { Area on which it } \\
\text { is located }\end{array}$} & \multicolumn{10}{|c|}{ Affected site } \\
\hline & \multicolumn{2}{|c|}{ Mesial } & \multicolumn{2}{|c|}{ Middle } & \multicolumn{2}{|c|}{ Distal } & \multicolumn{2}{|c|}{$\begin{array}{l}\text { All three sites at } \\
\text { once }\end{array}$} & \multicolumn{2}{|c|}{ TOTAL } \\
\hline & $\mathrm{N}$ & $\%$ & $\mathrm{~N}$ & $\%$ & $\mathrm{~N}$ & $\%$ & $\mathrm{~N}$ & $\%$ & $\mathrm{~N}$ & $\%$ \\
\hline Vestibular & 189 & 47,6 & 9 & 2,3 & 107 & 26,9 & 13 & 3,3 & 318 & 80,1 \\
\hline Palatine/ Lingual & 42 & 10,6 & 2 & 0,5 & 31 & 7,8 & 4 & 1,0 & 79 & 19,9 \\
\hline Total & 231 & 58,2 & 11 & 2,8 & 138 & 34,7 & 17 & 4,3 & 397 & 100 \\
\hline
\end{tabular}

In addition, gingival enlargements were classified, the results of which are described in Table 3, with the majority being grade I, limited to interdental papillae (Figures 2 and 3) and consistent with the location on proximal surfaces, detailed in Table 2.

Table 3 Gingival enlargement classification.

\begin{tabular}{|l|l|l|l|}
\hline \multirow{2}{*}{} & Grade* & \multicolumn{2}{l|}{ Surfaces } \\
\cline { 3 - 5 } & & N & $\mathbf{\%}$ \\
\hline \multirow{3}{*}{ Classification } & Limited to interdental papillae & 372 & 93,7 \\
& Affects the papillae and marginal gums & 25 & 6,3 \\
\hline Total & Covers 3/4 parts or more of the crown & 0 & 0 \\
\hline
\end{tabular}

The GE location in the 69 patients was divided into three groups: upper maxilla 10 (14.5\%), lower maxilla 16 (23.2\%) and both maxillary 43 (62.3\%) (Figure 4); as well as gingival enlargement per piece, as detailed in Table 4, with a higher frequency in the mandibular central incisor group with $17.6 \%$ (Figure 5).

Table 4 Distribution of gingival enlargement by tooth piece.

\begin{tabular}{|c|c|c|c|c|c|c|c|c|c|c|c|c|c|c|c|c|c|}
\hline & \multicolumn{17}{|c|}{ Pieza dental } \\
\hline \multirow{7}{*}{$\begin{array}{l}\text { Mouth } \\
\text { quadrant }\end{array}$} & & \multicolumn{2}{|c|}{$\begin{array}{l}\text { Central } \\
\text { incisor }\end{array}$} & \multicolumn{2}{|c|}{$\begin{array}{l}\text { Lateral } \\
\text { incisor }\end{array}$} & \multicolumn{2}{|c|}{ Canine } & \multicolumn{2}{|c|}{$\begin{array}{l}\text { First } \\
\text { premolar }\end{array}$} & \multicolumn{2}{|c|}{$\begin{array}{l}\text { Second } \\
\text { premolar }\end{array}$} & \multicolumn{2}{|c|}{$\begin{array}{l}\text { First } \\
\text { molar }\end{array}$} & \multicolumn{2}{|c|}{$\begin{array}{l}\text { Second } \\
\text { molar }\end{array}$} & \multicolumn{2}{|c|}{ TOTAL } \\
\hline & & $\mathrm{N}$ & $\%$ & $\mathrm{~N}, 9$ & $\%$ & $\mathrm{~N}$ & $\%$ & $\mathrm{~N}$ & $\%$ & $\mathrm{~N}$ & $\%$ & $\mathrm{~N}$ & $\%$ & $\mathrm{~N}$ & $\%$ & $\mathrm{~N}$ & $\%$ \\
\hline & $\begin{array}{l}\text { Upper } \\
\text { right }\end{array}$ & 14 & 3,9 & 11 & 2,8 & 8 & 2,0 & 6 & 1,5 & 7 & 1,8 & 11 & 2,8 & 1 & 0,3 & 58 & 15,4 \\
\hline & $\begin{array}{l}\text { Upper } \\
\text { left }\end{array}$ & 15 & 3,9 & 18 & 4,8 & 16 & 4,2 & 14 & 3,8 & 15 & 3,8 & 17 & 4,9 & 6 & 1,5 & 101 & 26,9 \\
\hline & $\begin{array}{l}\text { Lower } \\
\text { Right }\end{array}$ & 32 & 8,7 & 28 & 7,5 & 18 & 4,5 & 5 & 1,5 & 7 & 1,8 & 9 & 2,4 & 4 & 1,5 & 103 & 27,4 \\
\hline & $\begin{array}{l}\text { Lower } \\
\text { left }\end{array}$ & 34 & 8,9 & 31 & 7,7 & 19 & 4,8 & 7 & 1,8 & 4 & 1,0 & 11 & 3,8 & 8 & 2,4 & 114 & 30,3 \\
\hline & TOTAL & 95 & 25,4 & 88 & 22,8 & 61 & 15,5 & 32 & 8,6 & 33 & 8,4 & 48 & 13,6 & 19 & 5,7 & 376 & 100 \\
\hline
\end{tabular}




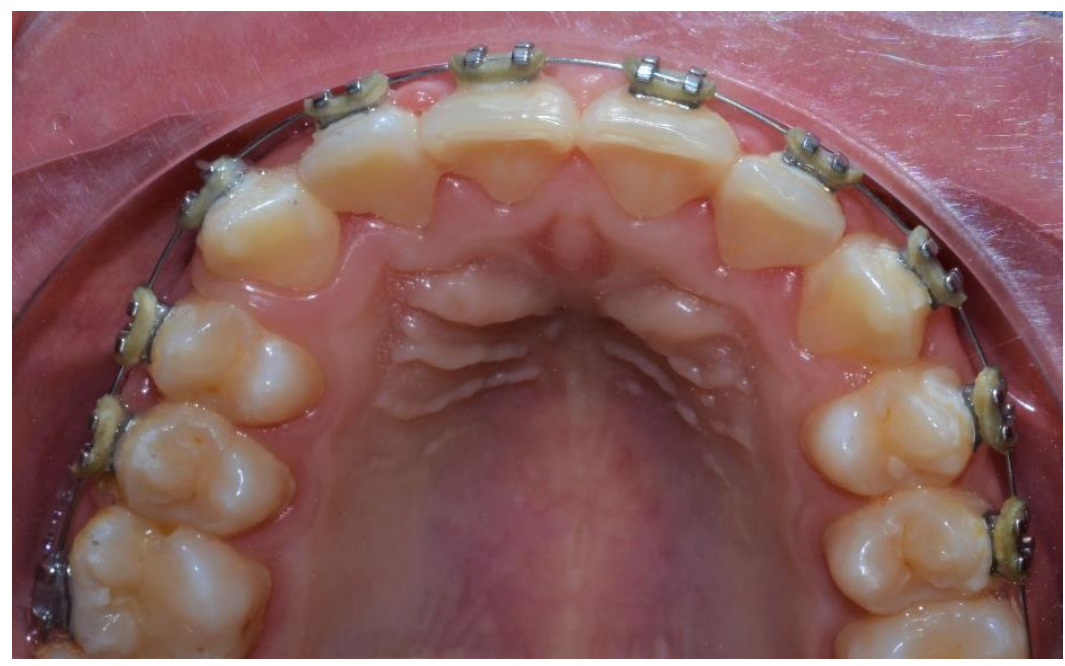

Figure 3 Gingival enlargement in vestibular and palatal interproximal areas of upper incisors, affecting the interdental papilla. Courtesy of graduate students of Orthodontics of the Faculty of Dentistry of the University of Cuenca.

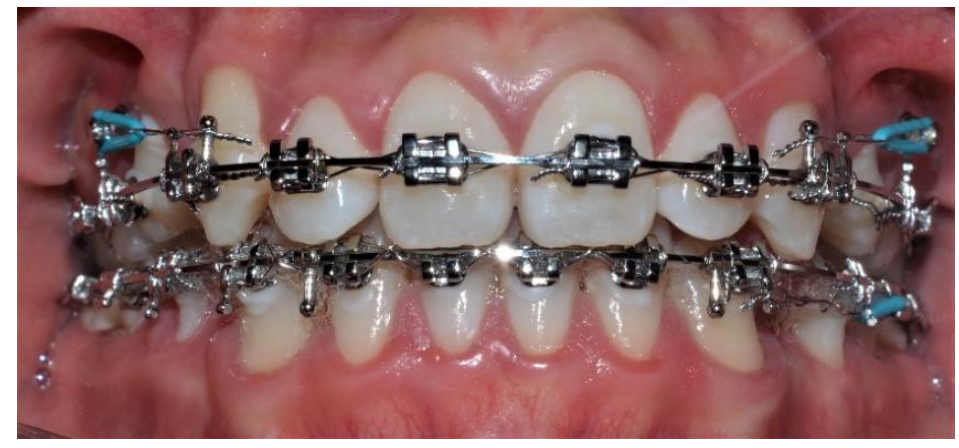

Figure 4 Gingival enlargement in the interdental vestibule-distal papilla with right maxillary lateral incisor. Courtesy of graduate students of Orthodontics of the Faculty of Dentistry of the University of Cuenca.

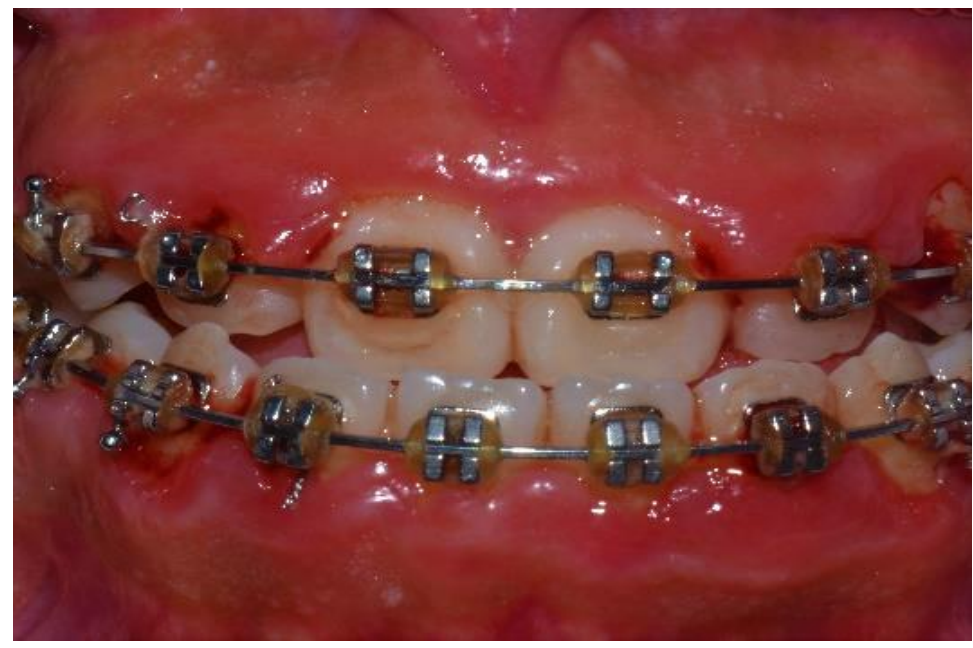

Figure 5 Bimaxillary gingival enlargement in the vestibular area, which predominated in the study. Courtesy of postgraduate students of Orthodontics from the Faculty of Dentistry of the University of Cuenca 


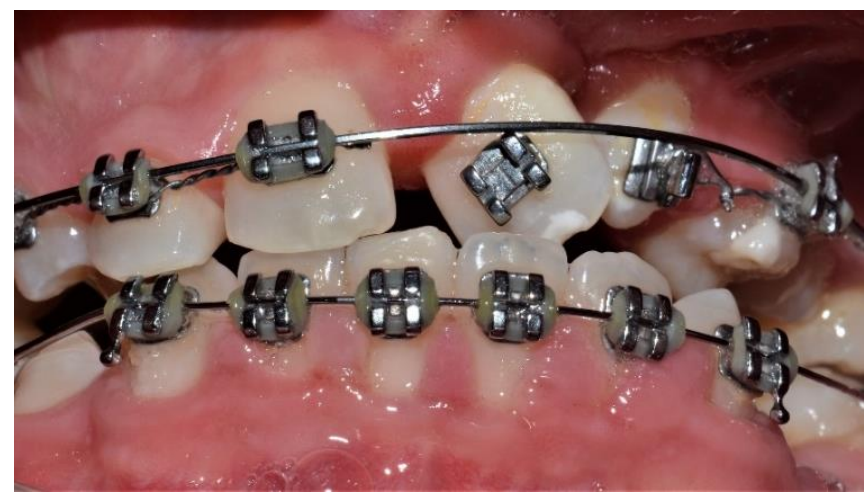

Figure 6 Gingival enlargement in vestibular anteroinferior zone. Courtesy of graduate students of Orthodontics of the Faculty of Dentistry of the University of Cuenca.

The association of gingival enlargement with the investigated variables was evaluated through the chi square test or the Fisher exact test, with a significance level less than $5 \%(\mathrm{p} \leq 0.05)$, as expressed in Table 5 . A unique association was found between the presence of gingival enlargement and the time of use of aparatology $(p=\mathbf{0 . 0 0 3 9})$; resulting that those patients who had been using fixed orthodontic aparatology for more than one year had 3.42 times more risk of gingival enlargement than individuals who carried this device for up to 12 months (OR: 3.42; 95\% CI: 1.46-8.02).

Table 5 Association between gingival enlargement and the studied variables.

\begin{tabular}{|c|c|c|c|c|c|c|}
\hline \multicolumn{7}{|l|}{ Gingival enlargement presence } \\
\hline \multirow[b]{2}{*}{ Variable } & & \multicolumn{2}{|c|}{ YES } & \multicolumn{2}{|l|}{ NO } & \multirow{2}{*}{$\begin{array}{l}\mathrm{X}^{2} \\
\mathrm{p} \text {-value }\end{array}$} \\
\hline & & $\mathrm{N}$ & $\%$ & $\mathrm{~N}$ & $\%$ & \\
\hline Age & $\begin{array}{l}16-25 \text { years } \\
26 \text { years or more }\end{array}$ & $\begin{array}{l}63 \\
6\end{array}$ & $\begin{array}{l}68,5 \\
46,1\end{array}$ & $\begin{array}{l}29 \\
7\end{array}$ & $\begin{array}{l}31,5 \\
53,9\end{array}$ & 0,1124 \\
\hline Sex & $\begin{array}{l}\text { Male } \\
\text { Female }\end{array}$ & $\begin{array}{l}29 \\
40\end{array}$ & $\begin{array}{l}65,9 \\
65,6\end{array}$ & $\begin{array}{l}15 \\
21\end{array}$ & $\begin{array}{l}34,1 \\
34,5\end{array}$ & 0,9715 \\
\hline Periodontal biotype & $\begin{array}{l}\text { Thick } \\
\text { Thin }\end{array}$ & $\begin{array}{l}40 \\
24\end{array}$ & $\begin{array}{l}66,6 \\
53,3\end{array}$ & $\begin{array}{l}20 \\
21\end{array}$ & $\begin{array}{l}33,3 \\
46,7\end{array}$ & 0,1658 \\
\hline Appliances usage time & $\begin{array}{l}\leq 1 \text { year } \\
>1 \text { year }\end{array}$ & $\begin{array}{l}17 \\
52\end{array}$ & $\begin{array}{l}47,2 \\
75,4\end{array}$ & $\begin{array}{l}19 \\
17\end{array}$ & $\begin{array}{l}52,8 \\
24,6\end{array}$ & $0,0039^{*}$ \\
\hline Bonding resin excess & $\begin{array}{l}\text { Yes } \\
\text { No }\end{array}$ & $\begin{array}{l}7 \\
62\end{array}$ & $\begin{array}{l}87,5 \\
63,3\end{array}$ & $\begin{array}{l}1 \\
35\end{array}$ & $\begin{array}{l}12,5 \\
36,7\end{array}$ & 0,1768 \\
\hline Prior detailing & $\begin{array}{l}\text { Yes } \\
\text { No }\end{array}$ & $\begin{array}{l}49 \\
20\end{array}$ & $\begin{array}{l}69 \\
58,8\end{array}$ & $\begin{array}{l}22 \\
14\end{array}$ & $\begin{array}{l}31 \\
41,2\end{array}$ & 0,3033 \\
\hline $\begin{array}{l}\text { Time from detailing to } \\
\text { cementation of equipment }\end{array}$ & $\begin{array}{l}\leq \text { a month } \\
>\text { a month }\end{array}$ & $\begin{array}{l}35 \\
15\end{array}$ & $\begin{array}{l}66 \\
78,9\end{array}$ & $\begin{array}{l}18 \\
4\end{array}$ & $\begin{array}{l}34 \\
21,1\end{array}$ & 0,2946 \\
\hline $\begin{array}{l}\text { Oral hygiene education and } \\
\text { motivation }\end{array}$ & $\begin{array}{l}\text { Yes } \\
\text { No }\end{array}$ & $\begin{array}{l}43 \\
26\end{array}$ & $\begin{array}{l}63,2 \\
70,3\end{array}$ & $\begin{array}{l}25 \\
11\end{array}$ & $\begin{array}{l}36,8 \\
29,7\end{array}$ & 0,4681 \\
\hline $\begin{array}{l}\text { Use of coluthora with } \\
\text { chlorhexidine }\end{array}$ & $\begin{array}{l}\text { Yes } \\
\text { No }\end{array}$ & $\begin{array}{l}9 \\
60\end{array}$ & $\begin{array}{l}69,2 \\
65,2\end{array}$ & $\begin{array}{l}4 \\
32\end{array}$ & $\begin{array}{l}30,8 \\
34,8\end{array}$ & 0,7754 \\
\hline
\end{tabular}

*Statistically significant value. 


\section{Discussion}

The gingival enlargement (GE) prevalence in the study population was 65.7\%; the most frequent GE degree was type I, i.e., at the papillary level, at 93.7\%; while the most common area was the vestibular at 80,1\%; and the most affected dental group was the lower central incisors with $17.6 \%$.

The GE prevalence in the study population was $65.7 \%$, which can be compared with the results published in 2017 by Vásquez et al. who conducted a study at the University of Honduras with 200 participants with fixed orthodontics, where a gingival enlargement prevalence of 55\% was determined [22]. Another study carried out by Borsa et al. evidenced the impact of fixed orthodontic devices on periodontal health where 193 patients were included, of which $49.7 \%$ showed excessive gingival growth [23].

On the other hand, a study carried out in China in 2019 (Zhao et al.) determined, among other factors, age as an influence in the improvement of oral and gingival health, while mentioning that it is negatively affected in elderly ages. This study supports the results obtained, since the increase in age showed a reduction in the prevalence of gingival enlargement from $68.5 \%$ in the group from 16 to 25 years to $46.1 \%$ in the group over 25 years [24].

Although the distribution of the prevalence of gingival enlargement was similar in both sexes, the literature indicates a greater susceptibility to gingival inflammation in the female sex, which is exposed to various hormonal changes during different periods of life with varying levels of estrogen and progesterone. These changes also have a significant influence on oral tissues as estrogen and progesterone receptors have been shown in the gums, in the periosteal fibers, in the dispersed fibroblasts of the lamina propria, and periodontal ligament fibroblasts that demonstrate the direct action of sex hormones on the periodontal tissues [25].

The determination of the gingival biotype is important to identify patients at risk with respect to conditions associated with the periodontium, Shiva et al. mention that the inflammation of the periodontium increases the formation of bags in the coarse biotype, while the thin biotype is associated with gingival recession [26]. This data coincided with the results obtained in this study, since $66.6 \%$ of the participants who presented the thick periodontal phenotype showed gingival enlargement; unlike 53.3\% present in those who had fine gingival phenotype.

Regarding the treatment duration, García et al. mentions that it is common to witness periodontal disorders in patients with the use of orthodontic devices for more than 18 months [27]. In the present study, a statistically significant association was found between gingival enlargement and the time of use of orthodontic fixed apparatus for more than 12 months (OR: 3.42; 95\% CI: 1.46-8.02). This data is supported by another study carried out in Rio Grande - Brazil, which included 260 patients, who were separated into 4 groups: a control group, patients undergoing orthodontic treatment for 1 year (10-14 months), for 2 years (22-26 months), and for 3 years (34-38 months); concluding that increasing data were found between the control group and the others, with a statistically significant association between gingival enlargement and permanence of orthodontic treatment. Patients with fixed orthodontic appliances presented a 20 to 28 times greater risk of gingival enlargement than those without orthopedics [28].

The excess of adhesion resin, in this case was not a relevant factor for the enlargement's origin, since its presence within the study was only $7.5 \%$, which is not significant. Scientific evidence indicates that removing excess adhesive around orthodontic attachments, despite their difficulty, is an important step in reducing the likelihood that dental biofilm will be retained [29]. Numerous investigations support the fact that the biofilm accumulation during fixed orthodontic treatment can be conditioned by factors such as the surface of attachment placement. Bruno et al. performed an evaluation that compared the amount of accumulation of dental biofilm between aparatology on vestibular and lingual surfaces, observing a gradual increase of clinical conditions in the first month, increase in bacterial plaque levels at three months, and increase in gingival bleeding after six months. However, the report does not refer the difference between lingual and vestibular accumulation, considering an equivalent risk [30]. Therefore, in patients with fixed orthodontics it is of vital importance an adequate management of oral hygiene, regardless of the area in question, thus avoiding possible complications that affect the health, aesthetics, and social development of the patient. Similarly, we mention the importance of the type of brackets as a source of pathogens accumulation. A study conducted in Seoul - Korea, selfaligning brackets were analyzed in 60 patients to evaluate the adhesion of periodontopathogens, concluding that although pathogens adhere to this type of bracket, they are nevertheless advantageous because of their reduced complexity structure, since the elimination of elastomeric or stainless steel ligation reduces retention sites, facilitating hygiene [31]. The literature also mentions that when comparing plain wire retainers and multilayer retainers, the latter report greater bacterial plaque accumulation, fiber reinforced retainers were also analyzed, which could be more counterproductive to the periodontium than wire retainers [32]. 
A consolidated relationship with the patient could determine the treatment success, as stated by Huang et al. additional efforts by orthodontists and hygienists could effectively motivate orthodontic patients to improve their oral hygiene [33]. In the present study, 37 (35.2\%) patients did not receive any hygiene education and from these 26 (70.3\%) presented GE. Thus, suggesting that periodontal control should be performed before, during, and after orthodontic treatment and not only at initiation, providing motivation and proper hygiene teaching, after the placement of the equipment and subsequent controls throughout the treatment.

A 2015 study in Brazil indicated that chlorhexidine varnish proved effective against gingival overgrowth in patients undergoing orthodontic treatment, recalling that chlorhexidine is considered the gold standard for the chemical control of dental biofilm [34]. In the present research, a reduction in the frequency of gingival enlargement was not found in those patients who referred to the use of chlorhexidine colloquia.

Finally, due to the cross-sectional descriptive study, it is not possible to establish cause-effect relationships, but only to determine the frequency of gingival enlargement, its distribution, and possible factors related. There was no control of the supragingival bacterial plaque level in the patients, therefore, the relationship between gingival enlargement and biofilm levels was not established; a fact that Batistin et al. reported through the clinical examination of 330 patients with fixed equipment, determining that $47.38 \%$ of the participants had elevated levels of visible dental biofilm in the mouth, and concluding that the gingival response with enlargement is common to the accumulation of dental biofilm in subjects undergoing orthodontic therapy [35].

\section{Conclusion}

With acknowledge of the study limitations, it is concluded that the prevalence of gingival enlargement in patients with fixed orthodontic appliances attended at the Postgraduate Clinic of the Faculty of Dentistry of the University of Cuenca, is $65.7 \%$, without statistically significant difference in sex, age, periodontal biotype, or periodontal treatment previously received. A statistically significant difference was identified in the orthodontic appliances use time, with a greater risk in those patients who have used orthodontic appliances for more than 12 months (OR: 3.42; 95\% CI: 1.46-8.02). The distribution of gingival enlargement was mostly in the vestibular surfaces $(80.1 \%)$, in the lower central incisor dental group (17.6\%), and were classified almost entirely (93.7\%) as grade I, that is at the papillary level.

Longitudinal research is recommended to include in greater detail the hygiene habits of patients and the levels of dental biofilm; as well as the evolution of periodontal tissues and their response to both periodontal therapy and the removal of orthodontic fixed apparatus.

\section{Compliance with ethical standards}

\section{Acknowledgments}

To the study participants, who allowed the execution of the research.

\section{Disclosure of conflict of interest}

The authors state that they have no conflict of interest.

\section{Statement of informed consent}

The present study was conducted with the informed consent of all the participants included in the study.

\section{References}

[1] Sioustis I, Martu M, Luchian I, Teodorescu C, Kappenberg-Nitescu D, Iovan A, et al. Clinical Effects of Orthodontic Treatment on Periodontal Status. Review. Rom J Med Dent Educ. 2019; 8(3):57-66.

[2] Casian A, Trejo P, León C, Carmona D. Hiperplasia Fibrosa Inflamatoria: reporte de un caso Inflammatory Fibrous Hyperplasia: case report. Rev clínica periodoncia, Implantol y Rehabil oral. 2011; 2(4):74-79.

[3] Colán A. Methods for the control of bacterial plaque during the post orthodontic fixed containment phase. Narrative review. Rev Cient Odontol. 2019; 7(2):52-63.

[4] Savage NW, Daly CG. Gingival enlargements and localized gingival overgrowths. Aust Dent J. 2010; 1(55):55-60. 
[5] Murakami S, Mealey BL, Mariotti A, Chapple ILC. Dental plaque-induced gingival conditions. J Clin Periodontol. 2018; 45(20):17-27.

[6] Candotto V, Pezzetti F, Baj A, Beltramini G, Lauritano D, Di Girolamo M, et al. Phenytoin and gingival mucosa: A molecular investigation. Int J Immunopathol Pharmacol. 2019; 33:1-5.

[7] Shimizu Y, Kataoka M, Seto H, Kido J, Nagata T. Nifedipine Induces Gingival Epithelial. J periodontol. 2002; 73(8):861-867.

[8] Archana, K, Dhanraj, M, Ashish, Jain, Nirosa T. Drug-induced gingival enlargement. Drug Invent Today. 2019; 10(7):1292-1295.

[9] Campolo A, Núñez L, Romero P, Rodríguez A, Fernández M, Donoso F. Agrandamiento gingival por ciclosporina: reporte de un caso. Rev Clínica Periodoncia, Implantol y Rehabil Oral. 2016; 9(3):226-230.

[10] Manzur I, Díaz I, Manzur D, Díaz A. Agrandamiento gingival farmacoinducido: Serie de casos. Univ y Salud. 2017; 20(1):89-95.

[11] Beaumont J, Chesterman J, Kellett M, Durey K. Gingival overgrowth: Part 1: Aetiology and clinical diagnosis. Br Dent J. 2017; 222(2):85-91.

[12] Newman, Carranza F. classification and epidemiology of periodontal diseases. In: Periodontology of Carranza's. Editorial. México: ELSEIVER Saunders; 2014; p. 84.

[13] Bhatnagar S. Treatment of Gingival Enlargement. Gingival Dis - A Prof Approach Treat Prev. 2019; 1-22.

[14] Nemţoi A, Scutariu MM, Nemţoi ANA, Eva L, Dumitrescu GF, Plămădeală P, et al. Clinical, imaging and histopathological correlations of gingival overgrowth: A retrospective analysis in northeastern romanian population. Rom J Morphol Embryol. 2019; 60(3):811-822.

[15] Simancas V, Díaz A. Aspectos morfológicos in vivo e in vitro de fibroblastos gingivales en pacientes con agrandamiento gingival. Entramado. 2020; 16(2):276-284.

[16] Angulo RS, Torre AC. Gingival enlargement resolution by means of non-surgical periodontal therapy: case report. Rev Odontológica Mex. 2016; 20(4):246-251.

[17] Mohamed NS, El-Zehery RRA, Mourad MI, Grawish MEA. Impact of three different mouthwashes on the incidence of gingival overgrowth induced by cyclosporine-A: A randomized controlled experimental animal study. Oral Surg Oral Med Oral Pathol Oral Radiol. 2015; 120(3):346-356.

[18] Chesterman J, Beaumont J, Kellett M, Durey K. Gingival overgrowth: Part 2: Management strategies. Br Dent J. $2017 ; 222(3): 159-165$.

[19] Lione R, Pavoni C, Noviello A, Clementini M, Danesi C, Cozza P. Conventional versus laser gingivectomy in the management of gingival enlargement during orthodontic treatment: A randomized controlled trial. Eur J Orthod. $2020 ; 42(1): 78-85$.

[20] De Rouck T, Eghbali R, Collys K, De Bruyn H CJ. The gingival biotype revisited: transparency of the periodontal probe through the gingival margin as a method to discriminate thin from thick gingiva. J Clin periodontol. 2009; 5(36):428-433.

[21] Moron M. Bacterial plaque biofilm-induced gingival hyperplasia in patients with orthodontic treatment . J Peruvian Assoc Periodontol Osseointegration. 2020; 4:44-52.

[22] Rodríguez AG, Fernández LK, Valladares EH. Prevalencia de agrandamiento y retracción gingival en pacientes con tratamiento de ortodoncia. Portal la Cienc. 2018; 13:21-31.

[23] Vincent S, Borsa L, Gruss A, Lupi L. Prioritization of risk factors of gingival hyperplasia during orthodontic treatment: the role of biofilm. BMC Oral Health. 2019; 1-15.

[24] Zhao Q, Shi Bin, Xu G, Song Y, Han X, Liu Z, et al. Periodontal health: A national cross-sectional study of knowledge, attitudes and practices for the public oral health strategy in China. J Clin Periodontol. 2019; 46(4):406-419.

[25] Zeba A, Bhardwaj S, Zeba J, Ashu B, Sawai M. Influence of female sex hormones on periodontium: A case series. J Nat Sci Biol Med. 2015; 6:146-149.

[26] Shiva M, Rana A, Sarkar A. Gingival Biotype Assessment in a Healthy Periodontium: Transgingival Probing Method. J Clin Diagnostic Res. 2015; 9(5):66-69. 
[27] Garcia A, Espinoza J, Garcia P. Gingivectomía como tratamiento para la hiperplasia gingival. Rev Mex Periodontol. 2019; 10(1-2):18-20.

[28] Pinto A, Souza A, Luana Z. Gingival enlargement in orthodontic patients: Effect of treatment duration. Am J Orthod Dentofac Orthop. 2017; 152(4):477-482.

[29] Ho CSF, Ming Y, Foong KWC, Rosa V, Thuyen T, Seneviratne CJ. Streptococcus mutans forms xylitol-resistant biofilm on excess adhesive flash in novel ex-vivo orthodontic bracket model. Am J Orthod Dentofac Orthop. 2017; 151(4):669-677.

[30] Bruno G, De Stefani A, Pillan M, Balasso P, Mazzoleni S, Gracco A, et al. Vestibular and lingual orthodontics: Experimental study on plaque and blood indexes. Minerva Stomatol. 2019; 68(6):285-290.

[31] Jung WS, Kim K, Cho S, Ahn SJ. Adhesion of periodontal pathogens to self-ligating orthodontic brackets: An invivo prospective study. Am J Orthod Dentofac Orthop. 2016; 150(3):467-475.

[32] Arn ML, Dritsas K, Pandis N, Kloukos D. The effects of fixed orthodontic retainers on periodontal health: A systematic review. Am J Orthod Dentofac Orthop. 2020; 157(2):156-164.

[33] Huang J, Yao Y, Jiang J, Li C. Effects of motivational methods on oral hygiene of orthodontic patients. Medicine (Baltimore). 2018; 97(47):1-8.

[34] Pretti H, Rezende G, Lopes E, Gala A, Moreira A. Effect of chlorhexidine varnish on gingival growth in orthodontic patients: A randomized prospective split-mouth study. Dental Press J Orthod. 2015; 20(5):66-71.

[35] Zanatta FB, Ardenghi TM, Antoniazzi RP, Pinto TMP, Rösing CK. Association between gingivitis and anterior gingival enlargement in subjects undergoing fixed orthodontic treatment. Dental Press J Orthod. 2014; 19(3):5966. 